\title{
Product Lot Number
}

National Cancer Institute

\section{Source}

National Cancer Institute. Product Lot Number. NCI Thesaurus. Code C94025.

An alphanumeric string used to identify a particular batch of the product. 